\title{
Identidad, memoria y arte popular: una mirada al centro cultural afro en el municipio de Tumaco (Colombia)
}

Identity, memory and popular art: a look at the Afro cultural center in the municipality of Tumaco (Colombia)

Luisa Fernanda Larios Beltrán ${ }^{1}$ Pontificia Universidad Javeriana, Bogotá D. C., Colombia https://orcid.org/0000-0001-9270-90066

Artículo de investigación

Fecha de recepción: 22 de noviembre de 2018 Fecha de aceptación: 9 de mayo de 2019

\section{Para citar este artículo}

Larios Beltrán, L. F. (2019). Identidad, memoria y arte popular: una mirada al centro cultural afro en el municipio de Tumaco (Colombia). Campos en Ciencias Sociales, 7(2), 75-124. DOI: https://doi.org/10.15332/25006681.5006

1. Comunicadora social. Correo electrónico: lfernanda.larios95@gmail.com 


\section{RESUMEN}

El municipio de Tumaco, ubicado al sur de Colombia, en el departamento de Nariño, ha atravesado momentos de cambio en los últimos 20 años. La situación de pobreza, el boom en el negocio de la coca, la violencia y la globalización han sido factores importantes para que la población afrodescendiente, ubicada en esta parte del país, cambie y deje atrás sus dinámicas identitarias y tradiciones. Sin embargo, ante esta realidad existen iniciativas de resistencia que la comunidad ha implementado para rescatar lo propio. Este artículo examina una iniciativa que se lleva a cabo en el barrio Nuevo Milenio y es el Centro Cultural Afro, el cual, a través de la identidad, la memoria y el arte popular, empodera a los nińos y jóvenes de esta comunidad para salir adelante y así dejar de lado el camino de la violencia. Asimismo, se expone cómo se ven estos jóvenes y cómo entienden su entorno.

Palabras clave: arte popular, globalización, hibridez cultural, identidad, memoria.

\section{Abstract}

The municipality of Tumaco, located in the south of Colombia, in the department of Nariño, has undergone moments of change in the last 20 years. The situation of poverty, the boom in the cocaine business, the violence and the globalization have been relevant factors for the Afro-descendant population who lives here, had changed and left behind its identity dynamics and traditions. However, faced with this reality, there are initiatives of resistance that the community has implemented to rescue their own identity and traditions. This article examines an initiative that takes place in the Nuevo Milenio neighborhood and it is the Afro Cultural Center, which, through identity, memory and popular art, empowers the children and youth of this community to get ahead and thus leave aside the path of violence. Also, this article shows how these young people see themselves and how they understand their environment.

Keywords: popular art, globalization, cultural hybridity, identity, memory 


\section{INTRODUCCIÓN}

De Tumaco se dice que es una de las ciudades más peligrosas de Colombia, que es un lugar donde todos los males del país están reunidos. No es un secreto que las guerrillas y grupos armados se han aprovechado de las circunstancias de pobreza de la población y el abandono del Estado para montar un negocio ilegal tan rentable como es el narcotráfico.

No obstante, hay un grupo de personas que lucha para cambiar esa realidad, personas que le apuestan al trabajo legal y al apoyo a su comunidad desde lo propio. Este es el caso del equipo del Centro Afro, un centro cultural que está ubicado en uno de los barrios más azotados por la violencia, el barrio Nuevo Milenio.

En este barrio hay aproximadamente 1500 casas y si por familia hay mínimo cuatro integrantes, habría en promedio 6000 personas viviendo en este lugar. Sus condiciones de vida son difíciles por el miedo y la inseguridad que existen en el barrio ya que en este se encuentra un grupo armado que está asociado al narcotráfico, alias El Tigre es el comandante de esta agrupación. La atracción al dinero hace que muchos jóvenes decidan cambiar el rumbo de sus vidas y hacer parte de grupos delictivos.

Teniendo en cuenta este contexto, la comunidad quería un espacio donde no se sintiera la violencia y que fuera como un segundo hogar para la juventud de este barrio que no estaba interesada en hacer parte de ese negocio delictivo, y es por lo que esta iniciativa del Centro Afro nació en el año 2009 gracias a la insistencia de los jóvenes para tener un espacio propio, un espacio para integrar a la comunidad y para realizar actividades lúdicas y culturales. Los misioneros combonianos ${ }^{2}$ jugaron un papel importante en la construcción de este lugar ya que su donación permitió la compra del lote y los implementos para su construcción.

Con el tiempo las actividades lúdicas que se realizaban con los niños y jóvenes del barrio Nuevo Milenio tomaron un propósito específico: guiarlos a sus metas

2 Los Misioneros Combonianos del Corazón de Jesús son una congregación religiosa clerical católica de derecho pontificio, fundada por Daniel Comboni en 1867, en Verona, Italia. 
y sueños, y de esta forma, evitar que vieran en la ilegalidad un plan de vida. Es por lo que, para llamar la atención de jóvenes y niños, se utilizaron recursos identitarios y culturales propios de la comunidad afrodescendiente como lo son las tradiciones, bailes, la música del Pacífico colombiano hibridada del rap, y de esta forma ofrecer otras alternativas desde el arte popular en el que la memoria y la identidad juegan un papel importante para formar a los niños y jóvenes de este barrio y así brindar oportunidades para que se proyecten a futuro y desde sus profesiones ayuden a su comunidad.

Considerando que los sujetos de estudio para esta investigación fueron los docentes, niños y jóvenes afrodescendientes que son activos en las actividades del Centro Afro, se partió de la relación de tres categorías: la identidad, la memoria y el arte popular. Estos configuradores de procesos culturales fueron observados en las prácticas comunitarias del Centro Afro a partir de un trabajo empírico analítico y teniendo en cuenta el contexto de la región, el cual será desarrollado en detalle más adelante.

Como punto de partida de esta investigación se plantearon distintas preguntas: ¿cómo los nińos, desde su entorno, entienden su territorio?, ¿cómo, desde la danza, se puede evidenciar el proceso identitario y de herencia cultural afro?, y ¿cómo desde la hibridación de las culturas en la música, se puede hacer memoria colectiva? Y como pregunta central se planteó lo siguiente: ¿de qué manera se construye la identidad a partir de procesos de memoria a través de arte popular en una comunidad local: el barrio Nuevo Milenio del municipio de Tumaco?

Teniendo en cuenta dicha pregunta, se propuso como objetivo principal evidenciar las representaciones sobre identidad y memoria a partir de las narrativas artísticas de los niños y jóvenes que participan de las actividades en el Centro Afro, ubicado en San Andrés de Tumaco, en el barrio Nuevo Milenio. Asimismo, describir cómo es el contexto social y de violencia, identificar cómo se pueden relacionar los actos de arte popular con el diario vivir de la comunidad y su identidad, y cómo los medios de comunicación y la globalización han permeado a la comunidad llegando a cambiar lo que se identifica como afro. 


\section{Antecedentes de la investigación}

Para un primer acercamiento a la identidad se revisó el trabajo de Payán (2014) que expone el caso de una escuela comunitaria ubicada en Cali, en el barrio Desepaz, llamada Sé quién soy, la cual está conformada por personas afrodescendientes y busca transmitir la cultura a las nuevas generaciones que no nacieron en el Pacífico o desde muy pequeños abandonaron su tierra. Por medio de la sistematización de experiencias la autora pudo identificar los saberes prácticos derivados de la experiencia educativa de la escuela comunitaria y, según esto, se pudieron establecer elementos que conforman la identidad cultural afro y así aproximarse a la comunidad y a sus creencias.

Otros trabajos que se tuvieron en cuenta para la investigación fueron los que tienen una conexión identitaria y de memoria con lo popular como el de Wade (1999), el cual se centró en un grupo de jóvenes afro que practicaba música rap y buscaban reivindicar la identidad negra en un contexto nacional. Por medio de entrevistas con los miembros de Ashanty y participación en charlas, reuniones y talleres con ellos, Wade muestra cómo esta agrupación se preocupaba por la cultura e identidad afrocolombiana vista desde las expresiones estéticas y la experiencia del racismo histórico que ha permeado la memoria afro y se reforzaba con referentes musicales estadounidenses, aterrizándolos al contexto colombiano.

En cuanto a la danza, se revisó la investigación de Olaya y Figueroa (2015) sobre el currulao como identidad cultural en Tumaco y por medio de un extenso trabajo de campo que incluyó entrevistas orales, textos, décimas, poesías, canciones y documentos audiovisuales, que arrojan resultados de una relación histórica, territorial, oral y cotidiana que identifican, crea pertenencia, es conservada y protegida por sus habitantes.

Asimismo, otra investigación para resaltar es la de Echeverría (2012) que trata sobre el teatro por la paz en Tumaco, y en el que por medio de características pedagógicas, sociales, culturales y terapéuticas, se apunta a la transformación del público. Se promueve el pensamiento crítico y reflexivo sobre la realidad social que está basada en la memoria de muchas víctimas y recopila las experiencias de ocho jóvenes y cuatro 
mujeres con el propósito de analizar cómo estos grupos han fomentado procesos de resistencia civil y participación ciudadana frente a las inequidades del Estado y la vulneración de derechos por parte de los grupos al margen de la ley.

Otro trabajo que configura la identidad en tiempos recientes es el de Restrepo (1999), en el que se exponen las identidades generacionales en Tumaco y cómo estas han cambiado con el crecimiento del municipio, en tanto ya no es una aldea de pescadores. Este documento es valioso para esta investigación ya que al tener alta documentación histórica y trabajo de campo, muestra cómo las nuevas condiciones sociales moldean a los jóvenes.

Tumaco: haciendo ciudad de Agier, Álvarez, Hoffman y Restrepo (1999), es otro trabajo de investigación que se revisó ya que posee un amplio espectro histórico, cultural e identitario de este municipio de la subregión del Pacífico Sur que se da por medio de ciertos grupos sociales. Este trabajo posee distintas experiencias teóricas y metodológicas de diferentes autores que ilustran el estado de Tumaco en cuanto a la cultura, identidad e historia y así devolverle su importancia en el panorama nacional.

También la investigación de Figueroa y Silva (2014) señala las condiciones identitarias (como las tradiciones y saberes populares) que han cambiado por el desplazamiento de las comunidades en el Pacífico Sur. Este trabajo expone la dificultad que tienen estas comunidades de mantener las tradiciones al ser despojadas de sus territorios ancestrales y al tener que reorganizarse en zonas marginales. Esto es importante ya que la comunidad del barrio Nuevo Milenio es desplazada de distintos corregimientos de Tumaco y sus integrantes han llegado a la ciudad por la violencia.

Una investigación que es más cercana al barrio Nuevo Milenio y al Centro Afro es la de Ensermua (2018), la cual hace visible las actividades de este centro y cómo estas han ayudado a que los jóvenes desarrollen procesos de sistematización y cambien su realidad y la de su ciudad. Lo anterior se llevó a cabo por medio de entrevistas y trabajo de campo. 


\section{Antecedentes históricos}

Se cita con frecuencia que la fundación de Tumaco data del año 1640, el 30 de noviembre, según el padre José Miguel Garrido (Jiménez, Hernández y Pérez, 2005). La historia de Tumaco y su proceso de crecimiento están altamente ligados a la del municipio de Barbacoas, pues este y sus alrededores fueron un centro de minería importante en la región que logró expandirse hasta las tierras de Tumaco, donde se introdujeron esclavos e indígenas para la extracción de materias primas.

Durante el siglo XVIII se fueron asentando las poblaciones: los indígenas ocuparon las cabeceras de los ríos y las zonas mineras fueron ocupadas por esclavos negros, este hecho aumentó y llegó a su punto más alto en el siglo XIX (García y Castillo, 1996). Este aumento de la población estriba en el estancamiento del sistema colonial y la poca rentabilidad de la esclavitud que se dio por el cambio demográfico a partir de la segunda mitad del siglo XVIII, en consecuencia, muchos esclavos comenzaron a comprar su propia libertad para así poder moverse por el territorio, dando origen a poblamientos en las bocanas de los ríos y en el interior de la selva (Jiménez et al., 2005).

Con la abolición jurídica de la esclavitud en 1851, muchos esclavos dejaron Barbacoas y se asentaron en Tumaco que más adelante se convertiría en el segundo puerto más importante de la región después de Buenaventura (Jiménez et al., 2005).. Así, al avanzar el siglo XIX, Tumaco vio una duplicación de sus habitantes, los ríos fueron ejes de poblamiento y la tagua, caucho y cacao se volvieron los principales productos exportados (García, 2003).

A medida que pasó el tiempo, en la ciudad de Tumaco ocurrieron dos hechos que marcaron su historia. El primero fue el incendio de 1947, un acontecimiento que acabó con todo el centro urbano de la ciudad pero que permitió la intervención del Estado para su reconstrucción. El segundo hecho fue el terremoto de 1979 de 7.9 grados en la escala de Richter que desató un tsunami y destruyó la ciudad. Este evento, según la Corporación Autónoma Regional del Cauca (CARC, 1983), llamó la atención del Gobierno y se buscó desarrollar proyectos para arreglar las zonas afectadas. Se creó el "Plan de desarrollo integrado de la costa pacífica". 


\section{Contexto social y político}

Según el Dane (2011), en Tumaco hay una población proyectada a 2020 que es de 221469 habitantes. El 88.8 \% de la población residente en Tumaco se autorreconoce como negra, mulata, afrocolombiana o afrodescendiente; el $5.1 \%$ como indígena y el resto no se reconoce en ningún grupo étnico (Dane, 2010). El $55.3 \%$ de la población reside en la cabecera municipal y el resto en la zona rural (Dane, 2015). Según información del Dane, la población tiene necesidades básicas insatisfechas, siendo los componentes de servicios, hacinamiento y dependencia económica los más críticos (Cámara de Comercio Tumaco, 2015).

Jorge Restrepo (2016) expone que el $81 \%$ de los cultivos de coca se encuentran en el sur del país y el resto está en otros departamentos. En el caso específico de Nariño, según este autor, Tumaco tiene 29755 hectáreas, la mayor cantidad del país. De hecho, el autor añade que son Nariño, Putumayo y Norte de Santander los que tienen el $64 \%$ de los cultivos (Restrepo, 2016).

Hubo un proceso que se llevó a cabo en esta región y fue el reconocimiento de tierras de la población negra. Al principio estos territorios fueron considerados por el Estado como baldíos ya que no estaban titulados jurídicamente, esto significaba que la población estaba invadiendo; sin embargo, para aprobar la titularidad se debían realizar mejoras en las zonas y esto podía afectar el medio ambiente y la relación simbólica de la población con su territorio (Jiménez et al., 2005). A mediados del siglo $\mathrm{XX}$, la situación se agravó ya que se determinó que el litoral constituía una reserva forestal del Estado sin tener en cuenta a la población (Arocha, 2004). No obstante, se reconocieron y se reglamentaron mediante la Ley 70 de 1993, normatividades jurídicas para que las poblaciones negras tuvieran titulaciones colectivas de territorios y así poder gestionar y fortalecer su organización priorizando su identidad y cultura (Jiménez et al., 2005). Para lo anterior se crearon los consejos comunitarios de los que actualmente en Tumaco hay catorce y que hacen parte de la Red de Consejos Comunitarios del Pacífico.

La distribución de la población se encuentra entre las áreas rurales y urbanas, pero según Jiménez et al. (2005): "esto suele cambiar con rapidez ante los vaivenes de 
los ciclos económicos, las atracciones o repulsiones generadas por las esperanzas exacerbadas de un nuevo puesto de trabajo" (p. 32).

Sin embargo, hace más de treinta años es evidente el éxodo rural y a partir de 1990 se han intensificado los flujos migratorios por la agudización del conflicto armado (Jiménez et al., 2005). Este fenómeno se ha dado ya que el Pacífico Sur ha sido una región olvidada por el Estado y es un lugar en el que son frecuentes las acciones delictivas. Para Jiménez et al. (2005):

La geografía del Pacífico sur sirve en la actualidad para orquestar la barbarie de la guerra, pues las diferencias y vínculos históricos entre sierra, piedemonte y llanura aluvial, que han marcado no solo lo geográfico, sino también lo étnico y lo cultural, son ahora una desventaja del área, en tanto que facilitan la movilidad de los frentes armados que buscan el control de enclaves fundamentales como Barbacoas, la carretera Pasto-Tumaco, los ríos, la línea costera, con sus posibilidades portuarias y comerciales. (p. 34).

Como se menciona, estos territorios son fáciles de apoderar, y al albergar una gran parte de su población en la zona rural, las condiciones de Tumaco favorecen que esta sea la mano de obra de los grupos armados ilegales que se enriquecen por medio del narcotráfico. En un artículo publicado por El Tiempo (2017a) se menciona que: "Tumaco, Narińo, se mantiene como el municipio más afectado, con 23148 hectáreas. Y en Nariño hubo en el último año un crecimiento del 43 por ciento: pasó de 29755 hectáreas en el 2015 a 46627 en el 2016" (párrafo 5).

Lo anterior ha generado una problemática social ya que, a pesar de que se firmó el acuerdo de paz entre el Gobierno y las Farc, nuevos grupos delictivos y disidencias se han apropiado de esas zonas que dejó esta guerrilla adueñándose del negocio de la coca. En el caso de los campesinos, muchos han firmado las cartas de compromiso para incorporarse en el cuarto punto del acuerdo -Solución al problema de drogas ilícitas- pero hay un conglomerado de estos que no quieren llegar a un acuerdo con el Gobierno ya que para ellos no existen garantías para cumplir con el pacto que se está realizando (El Tiempo, 2017b). 


\section{Movimientos cívicos y clientelismo político}

A pesar de la compleja realidad tumaqueńa, los movimientos cívicos han sido la fuerza para mantener a la ciudadanía junta, aquí se mencionan los más importantes que se han desarrollado y el escenario político tumaqueńo durante la historia y hasta la actualidad. Dicho escenario político se ha caracterizado por la lucha por los derechos civiles y el mejoramiento de la ciudad, según señalan Jiménez et al. (2005):

Tradicionalmente, Tumaco ha sido de filiación mayoritariamente liberal como un fenómeno de agradecimiento a la tendencia liberal liderada por José Hilario López que concretó, a mediados del siglo XIX, la abolición jurídica de la esclavitud, es decir, la finalización de tal forma de sujeción y discriminación de la gente negra y mulata esclavizada en minas, haciendas y casas de familias blancas. (p. 50).

A pesar de la lucha por los derechos civiles por parte de la población, el olvido del Estado que es evidente hasta la actualidad (Noticias Caracol, 2018) y su escasa regulación han permitido que se generen distintos escenarios de corrupción y violencia en el poder a lo largo de la historia de Tumaco, aprovechando así las situaciones de necesidad de la población.

Por más de treinta años, la historia política local tumaqueña ha estado marcada por personajes y redes familiares que han conseguido el poder por medio de prácticas sociales clientelistas, corrupción y reconocimiento social para lograr posiciones tanto en el ámbito regional como nacional (Jiménez et al., 2005). Una de estas redes familiares y que ha tenido un papel protagónico en la historia de Tumaco son los Escrucería, una familia de comerciantes prestantes que llegaron con los inmigrantes europeos a fines del siglo pasado para enriquecerse con la quina, la tagua, el cacao y el oro (Oviedo, 2009).

Samuel Alberto Escrucería Delgado, "Beto", logró una gran importancia ya que su discurso político sobreponía el reconocimiento identitario geográfico y regional de los pobladores, en distinción de la otra identidad serrana, pastusa y andina, que no sabía cuáles eran los problemas de Tumaco y generaba una opresión política 
(Rodríguez, 2004). Según Jiménez, et al.(2005), este político realizó campañas de forma familiar, reconoció a la gente por sus nombres y estableció vínculos como el apadrinamiento de niños. Fue de esta forma que Beto consiguió respeto y entró en el terreno de la política tumaqueña. Manejó este campo con su familia y sus amigos de entera confianza, logrando consolidar su feudo regional en Nariño por medio de manipulación, compra de votos y campañas electorales (Hoffmann, 1999).

Si bien Tumaco durante su historia ha tenido problemas de electricidad y de agua, después del terremoto de 1979 la situación empeoró para la población, ya que los políticos, en vez de buscar soluciones, utilizaron ese escenario para conseguir votos por medio de favores a la población, como contaba Lico Biojó en una entrevista a Oviedo (2009):

Beto se presentaba ante la Cruz Roja Internacional como el representante del pueblo y a él le entregaban todo y él disponía de estas ayudas a su antojo. En vísperas de elecciones de "mitaca" de 1980, él aprovechó este desastre natural y las donaciones, además del problema que estaba viviendo la gente, y así logró una gran cantidad de votos, que lo llevó a la Cámara de Representantes; como en esa época no existía el tarjetón electoral y el voto, por lo tanto, no era secreto, aquí, en Tumaco, los líderes betistas llegaban con el elector y lo llevaban como ganado al matadero, lo dirigían a la urna, ellos introducían la papeleta y los jurados se hacían los de la vista gorda, nadie veía nada. (p. 53).

Esto hizo reaccionar a unos ciudadanos que, cansados de estas injusticias, se unieron para buscar soluciones (Oviedo, 2009). El civismo surgió como una alternativa desesperada a todos los problemas, por primera vez los líderes que representaban estas juntas no eran parte de la clase política blanca, ahora eran poetas, pescadores y empleados públicos quienes representaban al pueblo tumaqueño (Oviedo, 2009). Lico Biojó, un empleado público, creó y lideró el primer comité cívico llamado la Junta Cívica de Mejoras y Defensa de los Intereses de Tumaco, como respuesta a los problemas de agua y energía eléctrica (Oviedo, 2009). Este movimiento convocó distintas marchas de protesta para el mejoramiento de los servicios públicos, pero no se quedó solo en esto, también denunció distintos actos de corrupción por parte de las juntas de acción comunal y la alcaldía de Otto Manzi, político betista, y la 
contaminación que generaban los derrames de Ecopetrol en sus fuentes hídricas (Oviedo, 2009).

\section{Grupos culturales}

Los colectivos y grupos culturales en la Perla del Pacífico se han conformado para resaltar los símbolos de identidad y de memoria de esta región. Muchos desde el arte como la música, la danza y el teatro han buscado rescatar esas expresiones de la zona. A continuación, se mencionan sus colectivos más representativos.

El informe del Ministerio de Cultura (2014) refiere que durante los años ochenta, cuando la población de Tumaco consideró importante articular discusiones y debates sobre la cultura, el territorio, la política e identidad por el proceso de la reforma constitucional de 1991, se creó un conglomerado de personas que como movimiento buscaron aportar a partir de lo cultural y lo comunitario a esta reflexión, haciendo énfasis en la subregión del Pacífico sur y la construcción de una versión específica y particular de lo afro con el Festival del Currulao.

Siendo Tumaco una población de poca importancia en el contexto económico del país, los planes de capacitación solo se incluyeron cuando los miembros de los grupos de danzas y teatro se dieron a conocer y cuando decidieron pedir apoyo en las instalaciones de Colcultura para ingresar en el sector cultural y ser objeto de desarrollo cultural. Para fortalecerse, estas organizaciones se constituyeron formalmente como la Alianza Cultural de Tumaco, este conglomerado buscó que lo cultural estuviera ligado con los procesos políticos, sociales y económicos de Tumaco, al tiempo que reivindicaba la importancia cotidiana de los saberes y prácticas que se expresan en la forma de vida de las comunidades afro e indígenas del municipio (Ministerio de Cultura, 2014)

Sobre las organizaciones culturales, la primera que se conformó fue el Grupo de Teatro Calipso, que durante la elaboración de la Ley 70 adoptó el nombre de Corporación Afrocolombiana Cultural Calipso; al respecto, Aristizábal (2005) afirma: 
Esta agrupación estaba orientada fundamentalmente a llevar a escena los episodios que marcaron dolorosamente a hombres y mujeres africanos al ser arrebatados de sus tierras y traídos por la fuerza a las costas del Pacífico, así como a mostrar las expresiones culturales que fueron creando y recreando en su nueva morada americana. Dada la especificidad que adoptaron en sus representaciones, al incorporar al lenguaje teatral moderno la problemática de la situación social del negro y sus manifestaciones culturales, lograron una buena aceptación a nivel nacional, llegando a obtener en dos ocasiones apoyos económicos. (p. 52).

En cuanto a la danza, la primera iniciativa también surgió en los ochenta por una empresa maderera que quería conformar una agrupación artística entre los empleados, no obstante, no solo hicieron parte ellos, también se invitaron jóvenes con talento para que se integraran a la iniciativa (Aristizábal, 2005). Dos años después de haberse disuelto el grupo varios jóvenes crearon nuevas agrupaciones, como explica Aristizábal (2005):

Estos jóvenes (Julio César Montaño, Francisco Tenorio, Nixon Ortiz y Gregorio) formaron sus propias agrupaciones, a saber: "Corporación artística danzas Ecos del Pacífico" (CADEP), "Fundación escuela folklórica del Pacífico sur Tumaco” y "Fundación folklórica Manglaria”. Aún (año 2002) subsiste el grupo madre, digámoslo así, el "Grupo Folklórico Danzas Negras”, dirigido por quien inició el proceso. Las agrupaciones mencionadas son las que inicialmente intervinieron en la organización del Festival del Currulao; el "Grupo Folklórico Danzas Negras" se retiró por diferencias de criterio, según opinión de su director en una entrevista. (p. 52).

Como se puede evidenciar, muchas de estas agrupaciones se crearon con el fin de preservar la música y las danzas de esa región. No obstante, se puede entender que estas manifestaciones culturales no están separadas de los ámbitos laborales, muchas veces las iniciativas comenzaban por grupos de trabajadores para divertirse y para preservar sus tradiciones. La mayor expresión de esto se puede evidenciar en el Festival del Currulao, que, si bien ahora está siendo manejado por personas y entes cercanos 
al poder, como la Alcaldía, sigue siendo un espacio para recordar las tradiciones de esta región.

\section{Las guerrillas y el narcotráfico en Tumaco}

Desde finales de los años ochenta, guerrillas como las Fuerzas Armadas Revolucionarias de Colombia (Farc) y el Ejército de Liberación Nacional (ELN) se asentaron en el territorio. El primer grupo, antes del acuerdo de paz con el Gobierno, tenía los frentes 8, 29 y 63 de las columnas Daniel Aldana, Jacinto Matallana y Mariscal Sucre. El segundo tiene presencia a través de las columnas Mártires de Barbacoas, Héroes de Sindagua y la compañía Camilo Cienfuegos (Ávila, 2014).

En cuanto a las Autodefensas Unidas de Colombia (AUC), el bloque Libertadores del Sur, del Bloque Central Bolívar, estuvo en el territorio desde 1999 y hasta el 30 de julio de 2005 (Ávila, 2014). Desde la desmovilización de las AUC en 2005 aparecieron bandas criminales. Según la Policía Nacional, en el departamento de Nariño delinque la Organización Nueva Generación, y según el Sistema de Alertas Tempranas de la Defensoría del Pueblo, hacen presencia las Autodefensas Campesinas Nueva Generación, Mano Negra y las Águilas Negras (Ávila, 2014).

Todos estos grupos armados ilegales y guerrillas, a pesar de sus ideologías opuestas y sus distintos propósitos, encontraron en este lugar del territorio colombiano una posibilidad para financiar sus luchas y lo lograron con el negocio de la coca. Ávila (2014) sostiene que inicialmente las Farc llegaron a finales de los noventa a Tumaco para controlar la producción de hoja de coca cuando se expandió en la región, y luego, en 1999, las AUC llegaron y se instalaron en el casco urbano de Tumaco y algunos corregimientos cerca al mar como Llorente y así coordinaron el aseguramiento de ríos, esteros y trochas del Pacífico nariñense.

Otras bandas criminales como Nueva Generación y las Águilas Negras han hecho presencia en Tumaco. Sobre la primera, se estableció su injerencia en el 2007, cuando amenazaron a distintas organizaciones sociales como Pastoral Social de la Diócesis de Tumaco y otras de ordenes sociales, indígenas y humanitarias (Ávila, 2014). 
Su interés se manifestó en mantener los cultivos de coca impidiendo la movilización social por programas de sustitución de cultivos, para lo cual amenazó y asesinó a campesinos cultivadores de coca que protestaron para pedir programas en ese sentido y a las instituciones a favor de la labor. Sin embargo, a mediados del año 2009, algunas autoridades y organismos de derechos humanos ya hablaban de su práctico desmantelamiento (Ávila, 2014, p. 29).

Posteriormente, en el 2003, los sectores sociales comienzan a visibilizar y denunciar las distintas violaciones al DIH por parte de la guerrilla de las Farc como los atentados a la infraestructura eléctrica y asaltos a buses intermunicipales (Barrera, García, Coronado, Hoyos y Guzmán, 2016). Por otro lado, la economía ilegal de las guerrillas en este territorio comienza a aumentar en la región y esto generó unas repercusiones en los pobladores rurales.

Afirman Barrera et al. (2016):

A partir de 2005, la movilización de los pobladores rurales se centra en la exigencia del cese a las fumigaciones a cultivos de uso ilícito porque afectan los cultivos de pancoger y los pequeños cultivos de palma aceitera, y en la solicitud urgente de programas efectivos de sustitución de cultivos. (p. 49).

Estas movilizaciones tuvieron eco para que hubiera una intervención por parte del Estado para combatir a la guerrilla, sin embargo, para 2011 se presentaron distintos problemas para la población civil. Barrera et al. (2016) cuentan:

Campesinos y pobladores urbanos hicieron varias manifestaciones para exigir el cese de los operativos militares contraguerrilla en zona rural del municipio, porque durante ellos se habían cometido graves infracciones al DIH. Desde entonces también serán continuas las marchas por la paz y contra las oleadas de violencia en Tumaco, que parece estar muy asociada con el despojo territorial a causa de macroproyectos de palma aceitera y camaroneras. (p. 49).

Desde finales de 2017, se han presentado distintos hechos que han perturbado las esperanzas de paz en el municipio, después de haberse firmado el acuerdo de paz 
entre el Gobierno y las Farc. Según un artículo de El Espectador (2018b), en esta región se están matando entre exmiembros del frente 29, que se encontraban en el Espacio Territorial de Capacitación y Reincorporación, y otros integrantes de las columnas móviles Daniel Aldana y Mariscal Sucre de las Farc.

Sobre la otra disidencia que hay en la región, que antes estaba comandada por alias Guacho, surgió cuando este disidente mediante el dinero, armas de narcos colombianos y emisarios de carteles mexicanos, retornó a la zona para recuperar los corredores de movilidad entre los ríos Mira y Mataje (El Espectador, 2018b). La última acción de esta disidencia fue el asesinato de los periodistas del diario El Comercio de Ecuador, quienes fueron secuestrados el 26 de marzo de 2018 en Esmeraldas, zona fronteriza con Colombia (El Espectador, 2018a). Asimismo, durante el mes de marzo y comienzos de abril de 2018, se reportaron varias explosiones de gran magnitud que afectaron las dos torres eléctricas de Tumaco, situación que dejó a más de 200000 personas sin servicio eléctrico.

En el municipio de Tumaco se han reunido todos los actores delictivos de la nación, y esto es debido a que ha sido una región conocida por el olvido de las autoridades y donde no hay una permanente regulación de los entes del Estado. Su posición estratégica en el océano Pacífico, la pobreza y las necesidades de la población, permiten que estos actores armados puedan construir espacios para que florezcan negocios ilegales como el narcotráfico.

\section{Aproximaciones conceptuales para pensar la memoria, el arte popular y}

\section{la memoria}

\section{La identidad a través de la lupa afrodescendiente}

Sobre la identidad, Hall menciona (1996): "la identificación se construye sobre la base del reconocimiento de algún origen común o unas características compartidas con otra persona, grupo o con un ideal, y con el vallado natural de la solidaridad y la lealtad establecidas sobre este fundamento" (p. 15). 
Sin embargo, esta construcción no es estática, de acuerdo a Jackson y Penrose (1993) la identidad es social y se construye culturalmente como un resultado de fuerzas históricas y geográficas determinadas y que cambian según el tiempo y el espacio, afirmando su carácter dinámico. Oslender (1999) explica:

Las teorías de construcción social contribuyen a desafiar nuestra conformidad con desigualdades que han sido justificadas mediante formas específicas de categorización realizadas por el poder dominante. Estas teorías nos animan a reevaluar dichas categorías deconstruyéndolas y exponiendo la rica diversidad que existe en su interior. (p. 28).

Dichas categorías han cambiado por medio del concepto de la diferencia, el cual antes poseía unas connotaciones negativas en los discursos dominantes de contextos racistas y colonialistas, y que ahora se usa por los llamados a celebrar la diferencia, dejando de lado la forma de entenderlo como algo negativo y usándolo desde una perspectiva progresista y positiva (Oslender, 1999).

Para efectos de esta investigación, Hall (1992) hace una contribución al concepto de negro como: "categoría organizativa de una nueva política de resistencia entre grupos y comunidades que en realidad tienen historias, tradiciones e identidades étnicas muy diferentes" (p. 252). Sin embargo, es importante no desviarse del contexto global. García Canclini, como Jackson y Penrose, concuerda en que la identidad no es estática, pero García Canclini (1994) hace un énfasis:

La definición de identidad no debe ser únicamente socioespacial, sino sociocomunicacional. Por lo tanto, tendrá que articular los referentes locales, nacionales y también de las culturas posnacionales que reestructuran las marcas locales o regionales establecidas a partir de experiencias territoriales distintas. La identidad se conforma tanto mediante el arraigo en el territorio que se habita, como mediante la participación en redes comunicacionales deslocalizadas. (p. 174).

Por esta razón García Canclini (1995) menciona que ya no se puede considerar a una sociedad como perteneciente a una sola cultura homogénea con una única identidad 
distintiva y coherente, ya que los símbolos y la economía traspasan las fronteras. En ese sentido, los procesos identitarios que se desarrollan en esta época de globalización son heterogéneos y multideterminados ya que las culturas se intersecan y coexisten con diferentes códigos simbólicos en los grupos, esto implica que hoy la identidad es políglota, multiétnica, migrante y hecha con elementos cruzados de varias culturas (García Canclini, 1995).

Dado que la identidad que se aborda en este artículo es la afrodescendiente, se tiene en cuenta que, como menciona Ramírez (2011), "es así como se le denomina a la población que nació de los sobrevivientes a la esclavitud en América en la época de la Colonia" (p. 31). Asimismo, Ramírez (2011) parafraseando a Suárez (2010), refiere: "los términos afrocolombiano y afrodescendiente son equivalentes, ya que el primero se desprende del etnónimo afrodescendiente y denota una doble pertenencia: tanto a las raíces negroafricanas como a la nación colombiana" (p. 31). Por tanto, la identidad afrocolombiana (según Mosquera, 2005, mencionado en Velandia, 2010), es:

El conjunto de imágenes construidas y asumidas por los afrocolombianos sobre sí mismos, basados en los valores y pensamientos construidos y desarrollados en forma autónoma o impuestos por los opresores en el pasado y el presente, en condiciones de explotación económica u opresión cultural. (p. 45).

Sobre lo anterior, Velandia (2010) menciona:

Sin embargo, la valoración que hacen los afrocolombianos sobre sí mismos puede estar basada en percepciones positivas o negativas de la realidad y de su historia. Por ello, la identidad afrocolombiana se construye sobre valores y los denominados antivalores, originados en situaciones como la discriminación, el racismo, la exclusión, que llevan a los afrodescendientes a pensar sobre sí mismos en términos de autoexclusión, negación de su cultura y de sus derechos, servilismo, deseo de "blanquearse" (imitar los rasgos culturales de los mestizos y los blancos para sentirse aceptados en la sociedad), inseguridad y subvalorización. (p. 45). 
De acuerdo a lo anterior, según Olaya y Figueroa (2015) la identidad afrocolombiana residente en Tumaco está representada por diversos imaginarios de las culturas híbridas, tales imaginarios exploran los aportes africanos, hispanos e indígenas que establecen conexiones entre música, oralidad y danza.

El hombre del Pacífico era netamente oral y el canto y la danza fueron las maneras que encontró de guardar en la memoria sus vivencias. La gente no solo llamó currulao a un baile, sino que también llamó currulao a todos los bailes de marimba ya que en esos bailes se van contando las historias del territorio (Olaya y Figueroa, 2015, p. 68).

Puesto que la danza y la música hacen parte del espacio identitario afrocolombiano ya que con estas herramientas resguardaron sus memorias, se explora a continuación su relación con la identidad. La danza puede surgir como ese método para compactar lo idealizado con el cuerpo, pues "nos permite hablar de la sevicia con la que nos hemos ensañado con el cuerpo, cómo lo hemos convertido en arma y territorio de guerra", como menciona Restrepo en una entrevista de la agencia EFE (2013). Según García (2015):

Esto ayuda a la percepción de la unidad personal y mental, ya que la danza es un medio para articular los procesos cognitivos, corporales y emocionales, a la vez que aporta a la buena salud de las personas, sin olvidar esa posibilidad de cambiar experiencias poco gratas. (p. 41).

La música, como la identidad, es a la vez una interpretación y una historia, describe lo social en lo individual y lo individual en lo social, la mente en el cuerpo y el cuerpo en la mente; la identidad, como la música, es una cuestión de ética y estética (Frith, 2003). Además, menciona:

La identidad no es una cosa sino un proceso: un proceso experiencial que se capta con tamańa intensidad, tanto una percepción del yo como de los otros, de lo subjetivo en lo colectivo más vívidamente como música. La música parece ser una clave de la identidad porque ofrece, con tamańa intensidad tanto una percepción del yo como de los otros, de lo subjetivo en lo colectivo. (p. 185). 


\section{Arte popular como un espacio para contar historias}

García Canclini (1977) define el arte como: "producción que consiste en una apropiación y transformación de la realidad material y cultural, mediante un trabajo y para satisfacer una necesidad social, de acuerdo con el orden económico vigente en cada sociedad" (p. 55).

Sabiendo que el arte satisface una necesidad social de acuerdo con un orden económico, García Canclini (1977) expone que el proceso artístico posee tres momentos: la producción, la distribución y el consumo. Dependiendo de cómo se modifiquen y sean sus interrelaciones se alcanzará un arte de liberación. Además, caracteriza tres áreas del sistema estético burgués: el arte de élites, el arte para las masas y el arte popular, y los vincula al proceso artístico. "El sentido elitista, masivo o popular es el resultado del modo en que se realiza la producción, la distribución y el consumo, y de la participación o exclusión de las diferentes clases sociales en el conjunto del proceso" (García Canclini, 1977, p. 73).

Para la realización de este trabajo se hizo un enfoque en el arte popular. García Canclini (1977) define el arte popular como:

Producido por la clase trabajadora o por artistas, pone todo su acento en el consumo no mercantil, en la utilidad placentera y productiva de los objetos que crea, no en su originalidad o en la ganancia que deje su venta; la calidad de la producción y la amplitud de su difusión están subordinadas al uso, a la satisfacción de necesidades del conjunto del pueblo. Su valor supremo es la representación y satisfacción solidaria de deseos colectivos. El arte popular es un arte de liberación. Para ello debe apelar no solo a la sensibilidad y la imaginación sino también a la capacidad de conocimiento y acción. (pp. 74-75).

El arte popular ha sido un medio de comunicación en el cual los ciudadanos de Tumaco han encontrado un espacio para expresar y plasmar sus experiencias, emociones e ideas. Pero como menciona bien García Canclini, su valor supremo 
es la representación y satisfacción solidaria de deseos colectivos. Como aduce Malo (1996): "la comunidad pesa más que el Estado y la expresión estética se pone de manifiesto tomando en cuenta los valores propios de la colectividad que se encuentran reforzados por la tradición” (p. 90).

Estas manifestaciones estéticas que se desarrollan en el Centro Afro son la danza y la música. La danza es una de las actividades más antiguas del hombre; por medio de ella, ha podido manifestar toda clase de sentimientos religiosos, sociales y culturales (Escobar, 2014). Asimismo, es una secuencia de movimientos corporales no verbales con patrones determinados por las culturas, que tienen un propósito, son intencionalmente rítmicos y tienen valor estético a los ojos de quienes la presencian (Garner, 2001).

En el caso de esta investigación, que está volcada hacia la comunidad afrodescendiente, para Olaya y Figueroa (2015) después de haber sido arrebatados de sus tierras para ser esclavos, la danza fue utilizada como una forma de olvidar sus penas, de llevar consigo y recrear en otras tierras algo que hiciera parte de su identidad cultural como lo son los instrumentos musicales, el ritmo, su simbología y sus significados.

Para estos autores el currulao cuenta la cotidianidad del tumaqueño, la forma como se enamora, la manera de pescar, las diferentes enfermedades que padece, la gastronomía y la enseńanza, esto quiere decir que el currulao no es solo una danza, son las expresiones, sucesos y sensaciones que hay en el diario vivir. Asimismo, los instrumentos musicales como la guasá, el cununo, la marimba y el bombo no solo emiten sonidos, también reflejan esta región del litoral por sus maderas, semillas y sus cueros (Olaya y Figueroa, 2015), y nos cuentan en las historias narradas por su creador de la forma como los elabora, de sus tiempos, de su fabricación y de su mística. Seguido a esto están las canciones que nos hablan de temas propios, vivencias, sucesos, comportamientos, cotidianidades en medio de música, baile y festejos que suenan a pueblo, a historia, a cultura (Olaya y Figueroa, 2015).

No obstante, la música, para los fines de esta investigación, es la que realiza el grupo Afromitu que hace parte del Centro Afro, y que posee un conjunto híbrido de 
elementos que representa a los ciudadanos de Tumaco y a los jóvenes del barrio Nuevo Milenio como la política, la corrupción, lo que para ellos es la identidad afrodescendiente y la cotidianidad a través del rap-consciencia. Sobre el rap, Wade (1999) menciona: "existe una identificación del rap con la autonomía negra y con la protesta social” (p. 273). Sobre esta inclusión del rap en la música de los jóvenes, el mismo autor refiere: "la hibridación es normal en un mundo en donde las imágenes y los sonidos se propagan a nivel mundial por los medios de comunicación” ( $\mathrm{p}$. 274). Si bien existe el uso del rap, que es de origen diferente al tumaqueño, se puede converger con lo que fue el afrocentrismo en EE. UU., el cual reivindica la importancia del origen africano y celebra los valores culturales y morales de las sociedades africanas (Wade, 1999).

\section{La memoria como construcción colectiva}

El arte no solo expresa las emociones y experiencias de las comunidades, también cuenta una historia, logrando, con actos como la danza y la música, que se evoque un acto de memoria. Según el Diccionario de Estudios Culturales Latinoamericanos de Szurmuk e Irwin (2009), la memoria se define como la remisión a un pasado que en algún momento quedó en el olvido y del cual surgen varias interpretaciones: pasado como un tiempo anterior, pasado como estructura de la verdad y pasado como experiencia traumática. Asi mismo, en el campo de la historia se realiza la reconstrucción de las memorias como diferentes modos de representación de los acontecimientos del pasado edificando sobre la selección o representación (consciente o inconsciente) de quienes escribieron o narraron la historia, son representaciones de representaciones y es por esto que se problematiza el concepto de "verdad histórica", entendida como verdad de los acontecimientos, restituida por el trabajo de interpretación subjetiva del historiador (Diccionario, 2009).

Sobre lo anterior, se entiende que no hay objetividades en esas historias y esto es debido a que los procesos de la memoria son sociales, es decir, que la gente recuerda solamente los acontecimientos que ha repetido y elaborado en sus discusiones con otros (Sautu, 2004). Halbwachs (1992) seńala que: "es en la sociedad donde la gente adquiere sus memorias. Es también en la sociedad donde ellos vuelven a recordar, 
reorganizar y localizar sus memorias" (p. 22). En ese sentido, el concepto de "memoria colectiva” refiere a las representaciones de hechos pasados, tradiciones, costumbres y prácticas sociales elaboradas intersubjetivamente y organizadas retóricamente (Middleton y Edwards, 1992).

Según lo mencionado, para Oslender (1999) es necesario que se recupere y se re-narre la historia negra del Pacífico de nuevas maneras. Si se entiende la historia como una serie de narrativas (Spivak, 1996), entonces es necesaria una narrativa propiamente negra. Lo anterior sin buscar verdades absolutas y contribuir al conocimiento de los terrenos locales, subrayando sus características específicas en un contexto histórico y geográfico particular, y al mismo tiempo admitiendo, de forma afirmativa y positiva, su carácter dinámico y variable en el tiempo y espacio (Oslender, 1999).

El estudio de las comunidades negras colombianas urbanas y rurales de la costa del Pacífico pone de manifiesto una lógica propia de construcción identitaria que se organiza alrededor de una relación especifica con el pasado; un régimen de memoria singular (Losonczy, 1999, p. 16).

Ese régimen de memoria singular se apoya en una estrategia de dispersión de los registros de la memoria y la tradición, poniendo la memoria explicita en la fundación de las comunidades ribereńas mediante relatos del tiempo poscolonial, rituales católicos, chamanismo, rituales africanos y, por otro lado, la autodenominación de libres, dejando de lado la huella de la esclavitud (Losonczy,1999).

Alrededor del olvido, los grupos negro-colombianos construyen su temporalidad, dominada por los distintos pasados y los registros culturales, de esta forma el paso de lo implícito a lo explicito permite encajar en la memoria (Losonczy, 1999). En cuanto a la actualidad de las comunidades negras, estas participan en la lucha por los derechos y por legitimidad en la escena nacional con las herramientas como la escritura, las cuales sirven para construir un fundamento que legitime sus derechos y les dé su lugar como sujetos de derecho en el espacio nacional (Losonczy, 1999). 
Una forma de visibilizarse es el uso de la música y la danza como representaciones de lo que elabora una comunidad, y esto permite la persistencia de la memoria debido a que son actos repetitivos. Sobre esto, Angulo (2014) afirma:

La música y la danza al ser repetitivas, evocar e invocar ancestralidad, se convierten en lo que Connerton llama la Memoria Incorporada, en la que se preservan imágenes del pasado sedimentadas en el cuerpo. Así, estas imágenes como elementos mnemotécnicos de los grupos sociales permiten la actualización del pasado en el presente, por lo cual la danza y la música, al ser procesos colectivos, reviven la memoria en la actual situación. (p. 33).

El simple toque de un tambor evoca estados corporales en los cuales se crea un lenguaje colectivo común, para esto no existen reglas, solo se siente, se escucha y se ve el sonido del instrumento, trasladando así a las personas a estados emocionales que les permiten recordar. (p. 34).

De esta manera las producciones artísticas ejemplificadas cumplen la función de provocar en el espectador la necesidad de reconstruir una memoria e historia colectiva, convirtiéndose de esta manera en una de las herramientas más eficaces (Francia, 2012, p. 6).

\section{Metodología}

El enfoque de investigación se desarrolló a partir de los estudios culturales latinoamericanos basados en el arte, la memoria y la identidad. Para Eduardo Restrepo en Richard (2010), los estudios culturales refieren a ese campo transdisciplinario que busca comprender e intervenir, desde un enfoque contextual, cierto tipo de articulaciones concretas entre lo cultural y lo político. Los estudios culturales surgieron en el contexto de la democratización de la cultura que acompañó la posguerra en Inglaterra. Sobre sus representantes, Szurmuk e Irwin (2009) señalan que los más importantes fueron Raymond Williams y Richard Hoggart, quienes se preocuparon por estudiar las influencias de la cultura popular en la clase obrera. 
Asimismo, estos pioneros tenían dos ejes para los estudios culturales y estos fueron la industria cultural y el énfasis en la cultura cotidiana de la clase obrera (Szurmuk e Irwin, 2009).

Por otro lado, los estudios culturales latinoamericanos han seguido varias de las líneas de debate de la tradición ensayística continental: la identidad latinoamericana, las idiosincrasias que distinguen la cultura latinoamericana de la europea o la estadounidense, la diferencia racial y el mestizaje, la transculturación y la heterogeneidad, y la modernidad, entre otros temas (Szurmuk e Irwin, 2009). Asimismo, se ocupan de las culturas marginadas o de comunidades desprestigiadas por su raza, sexo o preferencia sexual (Szurmuk e Irwin, 2009).

Según esta definición de los estudios culturales, la metodología de trabajo se realizó desde un análisis cualitativo a partir de las técnicas planteadas por Piergiorgio Corbetta (2007), quien explica que desde el punto de vista conceptual las técnicas de análisis cualitativo son todas técnicas de recopilación de datos.

A partir de las interacciones y las actividades de este centro, se utilizó un diario de campo en el cual se plasmaron las anotaciones que se tenían sobre las conversaciones, las acciones de los niños, jóvenes y profesores, y cómo se percibían los entornos.

Por otro lado, se realizaron entrevistas a profundidad que tuvieron como foco preguntas a los jóvenes e instructores en las que se evidenciaron las tres categorías de estudio de esta investigación: identidad, memoria y arte popular. Asimismo, fueron aplicados grupos focales, en los que se reunió a un pequeño grupo de personas para hacer contraste de datos. Se implementó con los jóvenes de 15 y 16 años que hacen parte del grupo de zancos en el Centro Afro. El objetivo era identificar cómo perciben este centro.

También fueron llevados a cabo talleres en los que se reunieron niños y niñas entre 7 y 13 ańos que se encontraban en la clase de danza. El primer taller tuvo como objetivo identificar la representación de identidad de las niñas y niños del Centro Afro mediante un dibujo y este era el animal con el que ellos se sentían identificados. 
El segundo taller tuvo como objetivo identificar la percepción de familia y territorio en los niños del Centro Afro, por lo que se les pidió dibujar en una hoja su casa y su familia.

Finalmente, se aplicaron historias de vida con las que se apuntaba a conocer la opinión de quienes frecuentan este lugar, como son los profesores y los jóvenes, y sobre los hechos que ocurren en el Centro Afro.

La documentación utilizada para esta investigación se enfocó en el contexto histórico, político y social de la región.

Por último, para poder ingresar a las instalaciones del Centro Afro, se contó con el permiso de la directora del Centro Afro, Uli Purrer, y la coordinadora Jenny Angulo. Se conversó con anterioridad con las fuentes para hacer las entrevistas. El trabajo de campo se realizó durante una semana.

\section{Hallazgos Y DisCUSión}

Esta investigación fue un ejercicio que buscó demostrar cuáles son las representaciones de memoria e identidad a partir de actividades artísticas como la danza y la música en los niños y jóvenes que hacen parte del Centro Afro, ubicado en San Andrés de Tumaco (Colombia), en el barrio Nuevo Milenio.

Teniendo en cuenta que la parte identitaria de esta investigación es la afrodescendiente, se puede concluir que las personas que hacen parte del Centro Afro poseen un reconocimiento de lo propio, como menciona Diana Quiñones, al preguntarle por qué enseña danzas tradicionales del Pacífico Sur:

Primeramente, porque es lo que yo sé, lo que yo manejo es la danza tradicional y la música y es lo que miré como una posibilidad de contribuir de lo social a todo este conflicto que hay en este territorio y segundo, porque sé que a través de la danza y la música casi todos se conectan en el Pacífico, a los niños del 
Pacífico les gusta la danza y la música. Entonces eso es lo que los conecta, eso es lo que les vamos a enseñar. (Comunicación personal, 29 de marzo de 2018).

Ese conocimiento de lo propio se puede explicitar también a la hora de realizar las canciones de Afromitu, la agrupación de rap-consciencia. David Rueda, uno de sus integrantes, menciona:

Nosotros lo que más rescatamos en el grupo son nuestras danzas, sentirnos orgullosos de cargar nuestro color de piel, porque tampoco es algo fácil en todas partes. Nuestra espontaneidad, nuestra alegría que nos caracteriza en Tumaco, la inocencia de algunos niños. Esas son las cosas que tratamos de rescatar en nuestra música. (Comunicación personal, 28 de marzo de 2018).

Asimismo, el sentido de pertenencia que poseen estas personas hacia su municipio se expresa en las canciones, como aduce James Banguera, integrante de Afromitu:

La canción "Mi tierra bella" va mezclada con cununo y un poco de marimba, y lo que tratamos tanto en las canciones como en los videos es mostrar un poco del colorido que identifica la gran gama cultural que tenemos dentro del municipio. En las letras tratamos de plasmar esa parte que nos identifica como que somos de acá de Tumaco, a veces hay frases que nos hacen identificar mucho, a veces nos comemos mucho las eses y las cambiamos como por una jota o algo así, o hay palabras que son muy típicas de acá, por ejemplo cuando hablamos de pachacajó. En algunas canciones, recordamos esos tiempos cuando uno podía ir a la calle y se quedaba en las esquinas, doce de la noche jugando. Todo eso hace parte de nuestra identidad y en algunas canciones tratamos de que queden bien fuertes. En "Mi tierra bella", hay cosas muy bonitas que decimos como: "Yo soy de la tierra de mi ñia". Mi ñia es una palabra muy de por acá que significa amigo, compañero. Utilizamos frases como jugo de chontaduro, jugo de borojó, encocado de pescado, cangrejo y jaiba, que son cosas que están dentro de la gastronomía y que nos hace muy ricos culturalmente. (Comunicación personal, 28 de marzo de 2018). 
Los tres testimonios anteriores dan cuenta de lo que Hall (1996) menciona en el concepto de identidad, y es el conocimiento de un origen en común, como es el caso de haber nacido en Tumaco y ser afrodescendiente, lo cual conlleva ciertas tradiciones y prácticas como la danza, la música, sus instrumentos, la forma de hablar o la gastronomía, entre otras. En el caso específico de Afromitu, lo que denota, como lo señalan Jackson y Penrose (1993) sobre el carácter social de la identidad y cómo se construye culturalmente como un resultado de fuerzas históricas y geográficas determinadas que cambian según el tiempo y el espacio, y es por esto que se puede encontrar la hibridez en este tipo de expresiones culturales, como lo es el rap.

La importancia de ayudar a la comunidad de los afrodescendientes se ve expresada en el trabajo de Diana. Asimismo, lo expresan los niños del Centro Afro al preguntarles sobre su proyecto de vida en el primer taller, como los dos siguientes ejemplos:

Figura 1. Resultado de taller realizado con los niños del Centro

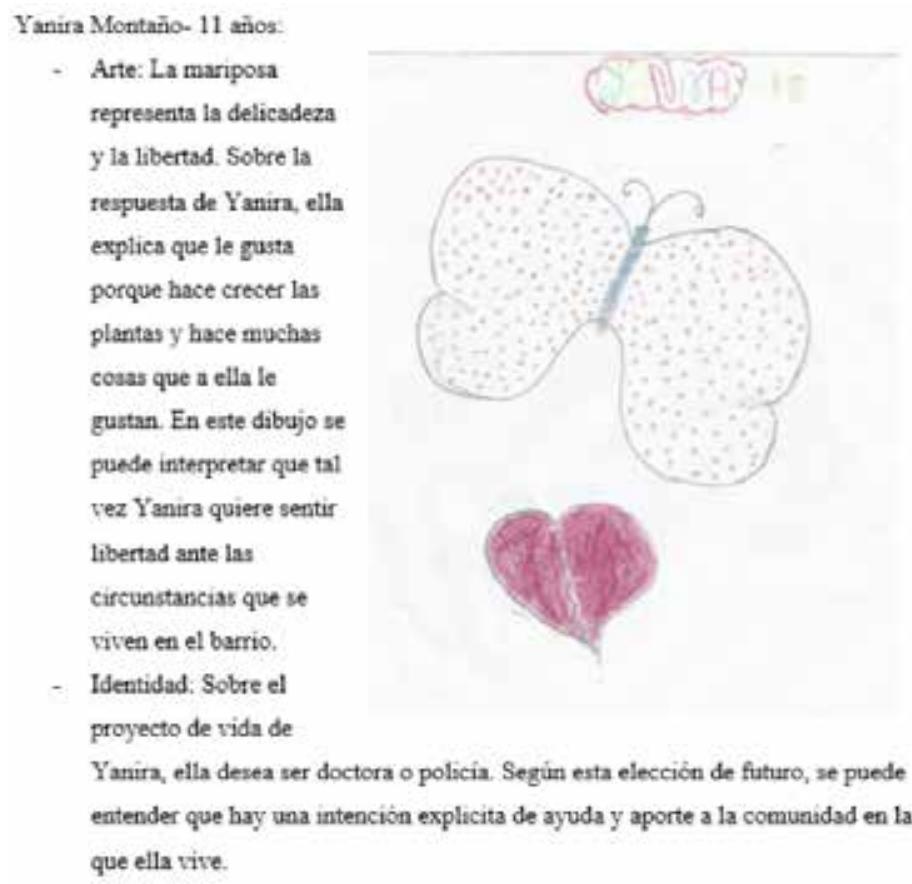


Fuente: Larios (2018).

Figura 2. Resultado de taller realizado con los niños del Centro

\section{Karol Guerrero - 11 años:}

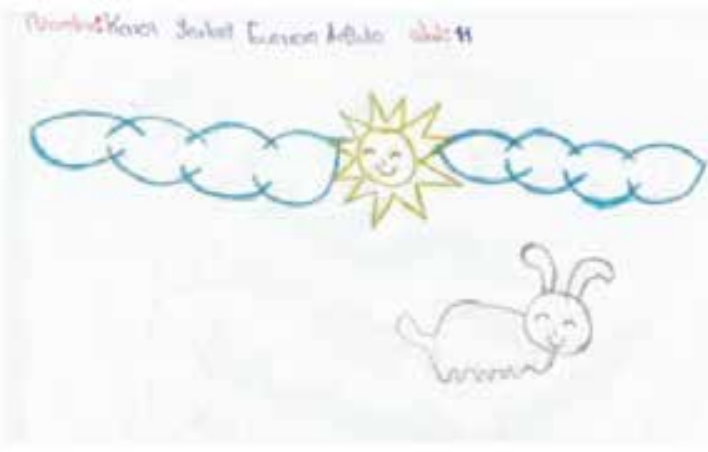

- Arte: El conejo es un animal que representa ternura, sensibilidad, bondad y el dinamismo. Para Karol, el conejo es muy cariǹoso, es bonito, juguetón y saltarin Por la sonrisa tanto en el conejo como en el sol, se puede percibir que ella se siente feliz o desea serlo.

- Identidad: Sobre el proyecto de vida, Karol quiere ser abogada, terminar sus estudios y ayudar a la gente. Esto explicita lo importante que es para Karol aportar a su comunidad.

Fuente: Larios (2018a).

La importancia de ayudarle al prójimo como parte de su proyecto de vida, profesiones u oficios como derecho, medicina, ingeniería o ser policía, puede aportar a la comunidad y al mejoramiento en la calidad de vida. Sobre esta idea, el Centro Afro ha proporcionado, según menciona Diana Quiñones:

Hay unas niñas con las que tengo muchos procesos, mucho tiempo con ellas y uno les preguntaba antes: ¿qué quieres ser?, y ni siquiera identificaban esa palabra. O sea: nada, "yo no sé". Y poco a poco se les ha dicho, por ejemplo, hay jueguitos que uno implementa que preguntan cosas como: ¿qué te gustaría ser? entonces a partir de ahí, como que dicen: “iprofe, yo no sé!”, entonces 
uno les empieza a decir posibles cosas, y ahí dicen: "ah eso es”. Y ya se han ido visionando. Antes decían mucho policía, y uno les decía ¿por qué? y respondían: "porque matan a los malos". Una vez otro me salió con que quería ser 'panda', porque tienen mucha plata, pero uno cómo les dice, uno como que es lo que ellos viven, eso es lo que ellos viven. (Comunicación personal, 29 de marzo de 2018).

Lo anterior se complementa con lo que busca enseñar el Centro Afro a los chicos del barrio Nuevo Milenio. Jenny cuenta:

Yo diría enseñarles mucha espiritualidad, confianza, optimismo y ganas de seguir luchando aún más allá, diría yo, porque cuando ellos están aquí ellos dicen: “¡nos gusta estar aquí!, ¡queremos estar aquí!”. Entonces es algo que a nosotros nos llena de satisfacción porque al menos estamos haciendo algo por ellos, y esa es la expectativa, que se puede hacer algo por ellos, por esos chicos. Nosotros buscamos enseñarles a los chicos esos valores, inculcarles mucho más de lo que reciben en las casas porque hay niños que en realidad no saben decir buenos días, buenas tardes o buenas noches, permiso, haga el favor, entonces son esas cosas que queremos rescatar de cada niño y que ese niño se valore por sí mismo, porque hay niños que andaban en condiciones muy, se podría decir, condiciones desnudas. Ya, entonces enseñarle eso, que un nińo o una niña debe aportar ropa a su cuerpo, proteger su propio cuerpo. Entonces eso es uno de los valores que hemos logrado, por lo menos, resaltar. (Comunicación personal, 30 de marzo de 2018).

Si bien existen, como menciona García Canclini (1977), representaciones y satisfacción de los deseos colectivos en el arte popular, este puede ser una herramienta de formación para los niños y jóvenes en donde se refuercen las tradiciones, la forma de vida afrodescendiente en la que lo más primordial es la comunidad y esta se debe apoyar por medio del proyecto de vida de estos niños y jóvenes.

3. La expresión 'panda' es usada coloquialmente por los ciudadanos tumaqueños para referirse a las personas que son narcotraficantes en la región. 
Sin embargo, lo anterior no se puede desligar del contexto de violencia que se vive en el barrio y en el municipio, ya que si bien las niñas entrevistadas tienen la intención de salir adelante, de ser profesionales y aportar a un mejor futuro para su comunidad, hay casos como el que menciona la profesora Diana Quińones, de un niño que quería ser 'panda', que significa narcotraficante, pero como bien menciona, eso es lo que viven los niños y para algunos es complicado escapar de esa realidad. Esto debido también a que los padres trabajan y es difícil que pasen mucho tiempo con sus hijos, por lo que mucho de lo que ven en el barrio los puede influenciar. No obstante, el trabajo del Centro Afro busca rescatar la infancia y enseñarles desde lo propio que existe un mejor futuro.

Pero lo propio se ha ido desdibujando por el gran flujo de información que hay por los medios de comunicación e Internet, y esto lo resalta García Canclini (1995) cuando señala que ya no se puede considerar a una sociedad con una sola cultura homogénea, en tanto los símbolos y la economía traspasan las fronteras. En ese sentido, los procesos identitarios que se desarrollan en esta época de globalización son heterogéneos y multideterminados ya que las culturas se intersectan y coexisten con diferentes códigos simbólicos en los grupos, esto implica que hoy la identidad es políglota, multiétnica, migrante y hecha con elementos cruzados de varias culturas.

Figura 3. Resultado de taller realizado con los niños del Centro

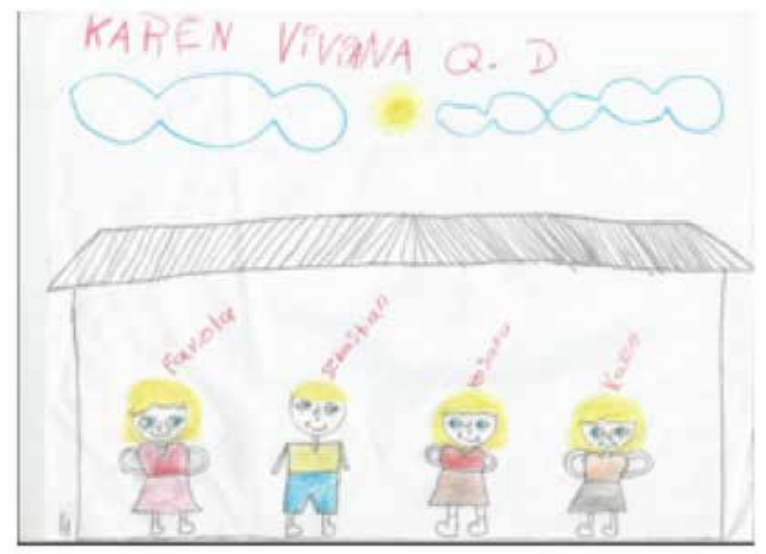




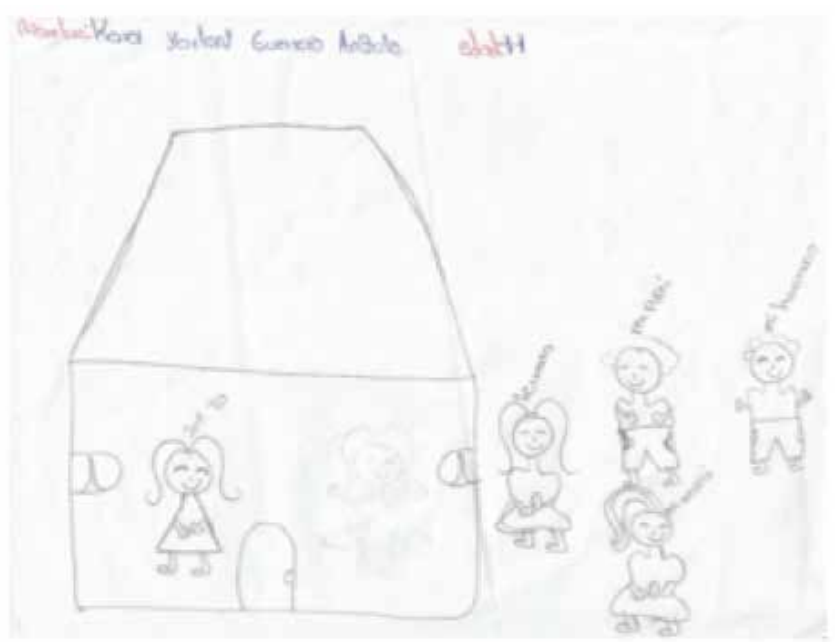

Fuente: Larios (2018b).

Lo precedente ha permeado a muchos niños con estéticas occidentales y por modos de vida diferentes a los que llevaban sus generaciones anteriores, a pesar de que con la música y las danzas se quiera reforzar el mensaje identitario. Lo anterior lo reafirma Jenny Angulo:

En cuanto a los jóvenes hoy en día, con lo que se entretienen es con Internet o en el mundo cibernético. Ya ahora uno no ve a los niños jugando ni a la ronda, nada, ni con balón, uno mira nińos con un celular. Entonces yo por eso digo que se ha ido perdiendo esa costumbre porque uno jugaba a la ronda, y ahora a un nińo uno le dice: ¡vamos a jugar la ronda! y dicen “¡ay qué pereza!”, o “jay no, ¿̨no hay otra cosa?!” Entonces uno dice: se ha ido perdiendo esa costumbre. Entonces aquí en el Centro Afro tratamos de que esa identidad no se pierda. A pesar de que unas cosas se han ido perdiendo, ellos son conscientes de que la identidad afro es hasta donde uno quiere llegar, porque ahí está reflejado con las niñas de danza, con los chicos de zancos, ya, entonces son cosas que ellos aún reflejan, y todos somos afro, nadie discrimina a nadie. (Comunicación personal, 30 de marzo de 2018). 
Sobre las estéticas en Tumaco, se califica al cabello crespo como "pelo duro" o "pelo malo", a pesar de ser propio de las comunidades negras. En contraste, los hombres portan el pelo rizado, el cual sí es aceptado socialmente. Sin embargo, hay una contraposición de estos rasgos occidentales con los cuerpos de los integrantes de las familias, los cuales son cuerpos robustos, propios de las comunidades afrodescendientes. Esto se observa en los dibujos que los niños realizaron para el segundo taller de familia y entorno (Figura 3).

Sobre esto, el Centro Afro ha intentado enseñarles y reforzarles a las niñas la importancia de apropiarse de su identidad, como menciona la profesora de danza Diana Quiñones:

A mí me pasó cuando yo era niña que yo me sentía fea porque tenía el pelo cortico, porque lo tenía duro, porque no me podía hacer una mońa y porque veía que todas las otras niñas tenían el pelo grande, o sea alisado, y se ponían extensiones. Todas esas cosas han sido duras para nosotras y para ellas aún. Niñas de doce o trece años que se alisan porque quieren hacerse una mońa que se les vea, pero entonces ahí estamos iguales reforzándoles: ¡Mis amores, no! este pelo es bonito, su boca grande es bonita, sus ojos grandes son bonitos, nosotros somos negros, nuestra nariz es ńata. $\mathrm{O}$ sea, yo siempre tengo que decirles por qué tenemos las piernas grandes, porque, por ejemplo, otra cosa es que la televisión nos muestra que las mujeres tienen que ser flacas, entonces las niñas me dicen: “Es que yo estoy gorda!”, no, nosotras somos así, entonces sí nos afecta, nos ha afectado muchísimo porque las niñas se sienten menos, se sienten vulneradas a la postura de los demás. Por eso ese refuerzo todo el tiempo de la identidad y de que nosotras somos así, nuestra etnia tiene esas características y que tenemos que valorarlas y que tenemos que vernos bonitos porque eso hace parte de nosotros y ellos son diferentes y nosotros somos diferentes y las diferencias hay que aceptarlas, entonces siempre estoy es con eso. (Comunicación personal, 29 de marzo de 2018).

La globalización ha permeado todas las culturas desde buenas y no tan buenas perspectivas. Lo positivo de la globalización es que el flujo de la información y de imágenes no está restringida y todos tienen acceso a estas. Lo negativo es que 
muchas veces esas imágenes ganan poder y se muestran como verdades absolutas. Autorreconocerse y aceptar la identidad, la cultura y las costumbres se vuelve complejo con ese gran flujo de información al que el ciudadano accede y es fácil que este se permee de esas nuevas cosas. Sin embargo, desde el Centro Afro hay una resistencia a olvidar.

Sobre el concepto de memoria, se pudo evidenciar tanto en los talleres como en el grupo focal, que cada día dentro del Centro Afro se construyen relatos, y son relatos desde el territorio, desde la forma en que viven y desde cómo se expresan. La actividad que rememora es la danza. La danza no es solamente seguir coordinadamente unos pasos, estas danzas cuentan varias historias que hacen parte de la memoria colectiva de la etnia afrodescendiente. Es en ella donde se guardan los recuerdos de un pasado difícil, como es el caso del baile negrito, sobre este, Diana menciona:

Particularmente las primeras danzas que yo le enseño a los niños es el negrito, que es una danza que tiene movimientos muy básicos como: arriba, abajo, a la derecha, a la izquierda y mueve la cintura. Son movimientos que en sí se ven muy básicos, pero la danza del negrito implica, aparte de que es algo fácil para ellos, una historia que va más allá, la danza de los negritos es una danza que enseña sobre la liberación de los negros, esa lucha, esa guerra, esa fuerza, ese hombre negro fuerte y que lucha. Y entonces habla del dios Changó y para nosotros el dios Changó es el dios de la guerra, el dios de la fuerza, pero nosotros no enfocamos a esa guerra hacia la agresión, si no a esa guerra de fuerza, de poder, de lucha, de superación. Entonces uno le enseña al niño y además de que también es esa alegría, esa espontaneidad del hombre negro, como que le permite liberarse, como que ya puedes hacer lo que quieras, ya no tienes que moverte así porque te lo dicen, no, ya puedes alzar las manos, ya puedes bajarlas, ya puedes sentarte, ya puedes hacer carambolas, ya puedes hacer trampolín. Es la primera vez que se le enseña al niño esa libertad, esa capacidad que tienes de hacer las cosas sin que nadie te limite. Desde ahí se le enseña al niño la danza de los negritos. Luego cuando el nińo ya asimila todo eso y ya se siente seguro, porque también es una danza para que le dé esa seguridad, ya puede dar una vuelta; si lo más duro para un niño es un trampolín 
o un para atrás, de ahí para allá va a hacer lo que él quiera. (Comunicación personal, 27 de marzo de 2018).

Esta liberación que se desarrolla en este baile también beneficia a los niños ya que hay una liberación en el cuerpo en tanto es una manera de reconocerlo, como menciona Diana:

Pues según mi apreciación, creo que les ha ayudado a conocer su cultura, a aprender de sus antepasados, un poco de historia, de cómo vivían antes los abuelitos. En lo que tiene que ver con su cuerpo creo que a reconocerlo y a conocer qué son capaces de hacer con este porque hay niñas que llegaban y me decían: “¡ay profe, a mí me da miedo hacer una carambola!”, o "profe ¡yo no puedo estirarme!", y a medida que el proceso se ha ido extendiendo ellas han reconocido su cuerpo, ellas saben que pueden hacer otras cosas, saben que pueden hacer volteretas, que pueden saltar, que pueden utilizar su cuerpo de muchas formas, creo que desde la parte corporal les ha ayudado muchísimo. (Comunicación personal, 27 de marzo de 2018).

Otra danza es el patacoré, la cual representa las enfermedades de las que sufrían los ancestros en el pasado cuando trabajaban en el campo, y tiene como fin enseñarles a los chicos que, si bien es bueno trabajar, hay que cuidarse a uno mismo. Por otro lado, también se les enseña a los jóvenes, pero cuando ya se van a graduar del colegio, la danza madre, que es el currulao, y que cuenta la historia de las reuniones, los domingos de marimba que se realizaban, las vestimentas y los ritmos de los instrumentos típicos como la marimba y el cununo.

Lo anterior refuerza lo que mencionaba Angulo (2014) sobre la memoria incorporada, la cual se logra con actos repetitivos como la danza, ya que esta evoca ancestralidad y conciente una actualización del pasado en el presente y permite recordar, como es el caso de las danzas, cómo era el pasado de las comunidades y cómo eran sus prácticas sociales.

En cuanto a la Afromitu, ellos tienen una intención de rememorar el pasado, recordando los buenos momentos que se vivían en el territorio antes de la violencia. 
Pero también sobre actos y personajes que hacen parte de la etnia afrodescendiente. Sobre lo anterior, James Banguera dice:

Nosotros como grupo, el tema de la memoria colectiva lo tenemos muy presente ya que tenemos muy claro, nosotros como afros que nos identificamos, que nuestros ancestros trabajaban mucho en equipo, el tema de la minga no es cualquier palabra que está ahí. Tiene un sentido de apropiación bien fuerte, es un lince, es trabajar para un bien común, es ir hacia una misma dirección, tratando de buscar el bienestar de todos. Entonces bajo esa cosmovisión nosotros en el grupo lo vemos, por eso Afromitu no es solo una agrupación musical sino que es una familia, es un lazo de amistad, es un proyecto en el cual queremos que todos vayamos siempre para el mismo lado y queremos que nuestro Tumaco sea una familia, sea un colectivo que trabaje por el bienestar de todos.

En nuestras letras tratamos de plasmar, recordar personajes como Benito Castillo, gran decimero, y hacerles un homenaje a personajes que en la actualidad siguen trabajando el tema de la oralidad como Pachín Carabalí, entonces digamos que en ese sentido recordamos y aplicamos. Y el tema de la oralidad es un tema bastante impregnado en nosotros y por eso hablamos tanto, eso nos hace muy alegres porque nos permite tener una gran gama para usar un sinnúmero de palabras, echamos mucha carreta, pero digamos que es algo que está dentro de nuestra historia de forma muy importante, porque gracias a esa oralidad nuestros ancestros nunca perdieron la ruta de lo que venían haciendo los otros ancestros de ellos anteriormente, entonces es como una ruta bien trazada de seguir pasando ese conocimiento de generación en generación a través de la oralidad, entonces digamos que tanto la oralidad como el tema de la minga son temas demasiadamente importantes para nosotros como afros. (Comunicación personal, 29 de marzo de 2018).

Conservar la historia permite que el hombre afro tenga un sentido de pertenencia tanto de su cultura como de su territorio. Por esto la importancia de lo que menciona Oslender (1999) sobre recuperar y volver a narrar la historia negra y ver cómo desde 
distintas narrativas, como lo es el rap-consciencia, tienen un poder de contribuir a estos conocimientos de terrenos locales, expresando lo que los caracteriza, como menciona James Banguera.

Al ser el Centro Afro un lugar donde se les enseña valores a los jóvenes y un lugar donde se construyen memorias, estos crean un vínculo con el mismo, incluso en el mismo barrio, a pesar de la violencia que se vive. En el caso del Centro Afro, para los jóvenes del grupo focal, este lugar es para ellos una segunda casa, es un lugar donde se sienten felices y donde ellos mismos también construyen memorias, como lo expresa Diego Andrés Angulo Quiñones, joven zanquero de 16 años: “para mí el Centro Afro es algo que me motiva para ser alguien en la vida. Lo que más me gusta de venir al Centro Afro es venir a montarme en los zancos, a recrearme con mis amigos”.

Asimismo, al tener recursos como computadores, los niños y jóvenes tienen un lugar para hacer sus tareas. De esto se infiere que pueden pasar mucho tiempo en este sitio, sin contar cuando están haciendo las actividades que ya han sido programadas en el Centro Afro.

Esa apropiación del lugar también está ligada a la apropiación del barrio. Al preguntarles a los niños en el segundo taller sobre qué sitio les gusta, tanto el Centro Afro como el barrio son mencionados. Aunque existe una particularidad en el barrio Nuevo Milenio y es que según Uli Purrer, la directora del Centro Afro, el $80 \%$ de las familias que viven en este son campesinos que llegaron a la ciudad para que sus hijos estudiaran o porque eran desplazados de la violencia. Sobre esto, Jenny Angulo menciona:

Pues hubo un tiempo que hubo mucho desplazamiento. Entonces esas personas llegaron a Tumaco y se reubicaron aquí. Pero en tiempo de vacaciones ellos vuelven, pues se supone que, ya ha habido una calma, una paz, entonces por eso ellos vuelven a retomar sus lugares. Porque pues tienen sus fincas, sus gallinas, los ganados, lo que sea, entonces por eso ellos vuelven. O porque si se van un fin de semana, vuelven a la semana y regresan o en tiempo de vacaciones que, como te lo decía, cuando hay vacaciones de colegio, siempre 
se da que ellos siempre se van hacia la vereda. (Comunicación personal, 30 de marzo de 2018).

Volviendo al tema del barrio, los niños, a pesar de ser conscientes de la situación de violencia y conocer de los peligros, es en este entorno en el cual se sienten felices. Y lo saben porque sus padres y en el Centro Afro se lo repiten constantemente, como menciona Diana Quiñones:

Y usted les pregunta: ¿para dónde les da miedo ir? ¿A qué le tienen miedo? Y responden que para la invasión o ahí para el aserrío. Son las palabras que ellos te dicen, que uno sabe que allá es donde es, porque ellos también conocen, porque los papás les dicen y nosotros les decimos para donde no pueden ir. Entonces así es el día a día de ellos. Hay días que escuchan los tiros y se quedan ahí parados y ni se mueven y me toca decirles: ¿̨no están escuchando? (Comunicación personal, 29 de marzo de 2018).

Entre las respuestas sobre a qué le tienen miedo, existe un patrón sobre la violencia que se vive en el barrio como la presencia de narcotraficantes, las balaceras y los lugares donde están concentrados los grupos armados. Esto nos expone que existe un miedo constante en el territorio, y como menciona Leonardo Castro:

Hasta en mi barrio me siento inseguro, aquí no me siento seguro. Fíjese que aquí hay un sector que le llaman el Pindo y yo, que pertenezco al barrio Nuevo Milenio y yo ahí no paro, ese semáforo puede estar en rojo y yo paso derecho. Porque esa incertidumbre de qué te puede pasar, de pronto por equis o ye motivo se encuentran dos enemigos por una guerra absurda, que ni siquiera ellos saben por qué pelean o por qué comenzó. Entonces eso hace que uno permanezca con esa alerta. Cualquier sonido que no sea coherente, uno dice: ¿qué pasó? y uno está listo para correr, para esconderse. Esa es la tensión que se vive básicamente. (Comunicación personal, 28 de marzo de 2018).

Con lo mencionado, se puede concluir que tanto los niños como los jóvenes se construyen a partir de un contexto de violencia, y que, hasta que las circunstancias 
no cambien, los chicos crecerán con un miedo constante, pero este se adaptará ya que es allí donde construyen sus memorias y sus vidas.

En cuanto al arte popular, este se ha convertido en la rama que sostiene las actividades del Centro Afro, ya que es con este arte que ha logrado enganchar a los niños del barrio Nuevo Milenio. Lo primordial, que ha sido la danza, se utiliza como herramienta para la transformación social, según cuenta Diana:

\begin{abstract}
Cuando ya hablamos de la música qué me genera cuando quiero utilizarla como una herramienta, cuando se la enseño a mis chicos, yo la veo como una herramienta de transformación social, de cambio. Como yo digo: ¡cómo yo través de esta danza, de esta música que enseño, cómo puedo hacer que cambie la vida de manera significativa de ese niño? Entonces ya es otra cosa para mí, entonces la danza para mí es una herramienta de transformación social, la utilizó para mostrarles otra perspectiva de la vida a los chicos, otra manera de ver la vida, otra forma de vivir, otra manera de salir adelante. (Comunicación personal, 27 de marzo de 2018).
\end{abstract}

Ese cambio social, ese objetivo comunitario que menciona García Canclini (1977) que se busca con la danza local, deja de ser solo una actividad de entretenimiento para volverse una actividad con una motivación clara: que los chicos vean que desde lo cultural se pueden encontrar otros caminos distintos a la violencia.

En el caso de la música que hace Afromitu se busca lo mismo. La intención, para este caso, es que los jóvenes que consumen su música cambien la mentalidad, ya que como menciona David Rueda:

Aquí en Tumaco la situación de violencia es bastante difícil. Si uno sale a la calle, uno sale con miedo porque es probable que no vuelva más. Por lo menos ahoritica estamos aquí y no sabemos en qué momento suenan los tiros y las balaceras, no sabemos. Siempre estamos con la psicosis y el miedo. Entonces queremos que los jóvenes en vez de coger un arma para hacer daño, mediante 
la música, especialmente el rap, expresen lo que sienten y eviten meterse a ese tipo de cosas. (Comunicación personal, 28 de marzo de 2018).

Asimismo, la música que se utiliza es el rap, y en este se ve lo que se mencionaba, la incursión de nuevos mensajes por la globalización como menciona Wade (1999) en su investigación. Sin embargo, desde el centro apuntan a impactar a los jóvenes desde las situaciones locales, como anota James:

El rap desde sus inicios ha sido una herramienta para la transformación social, para visibilizar los derechos, entonces nosotros utilizamos esa herramienta porque digamos que es una forma no violenta de decir las cosas. Una forma artística y alegre de poder plasmar a veces lo que no se puede decir, a palabras crudas. Por medio de la música podemos transmitir nuestros pensamientos y que no queden en el contexto local, sino que esa información pueda llegar a otras partes, que por medio de una canción se sepa que Tumaco también es parte de Colombia, que Tumaco no es solo violencia, y que en Tumaco hay un sinnúmero de jóvenes que le apuestan al arte, que le apuestan a una forma diferente de ver las cosas, y que existen formas diferentes de manifestar las cosas sin llegar a la agresión física, como lo es la música y en este caso lo que es el rap-consciencia, entonces desde esa perspectiva el rap y la cultura del hiphop nos permite expresarnos y decir lo que sin la música no seríamos capaces de decir por el miedo. (Comunicación personal, 29 de marzo de 2018).

Para finalizar, se puede concretar que las tres categorías conceptuales que se trabajaron han mutado según el contexto que hay en la región, un contexto donde el desarrollo de la ciudad, la apertura de Internet y los medios de comunicación han cambiado los significados desde la parte identitaria y los valores que, según la etnia afrodescendiente, hacían parte de sus características. En cuanto a la memoria, esta se ha visto afectada por lo mismo, sin embargo, tanto para la identidad como en la memoria, el Centro Afro quiere recordar esos valores que hacen y que caracterizan a los afrodescendientes, desde su música y sus actividades. Por último, estas actividades se logran enganchar a partir del arte, que es interesante para los nińos y que tiene un fin para que ellos tengan un mejor futuro. 


\section{ConClusiones}

Como se puede evidenciar en el desarrollo del contexto presentado de San Andrés de Tumaco, es el olvido histórico por parte del Estado el que ha generado falta de oportunidades para la comunidad, desempleo, desprotección, y la no garantía de bienes básicos como la luz y el agua. Esta desprotección ha permitido que la ilegalidad abunde, y en las zonas apartadas se concentren y crezcan negocios como el narcotráfico, que actúan de la mano de los grupos armados.

Se han dado iniciativas desde grupos cívicos y colectivos culturales para reclamar por esas necesidades y para denunciar hechos de violencia, sin embargo esto no ha sido suficiente para que las autoridades respondan de manera adecuada. Esto ha generado que la misma población deba valerse por sí misma y aceptar las situaciones que suceden, acostumbrándose a vivir con miedo.

Teniendo en cuenta que en los resultados de los talleres y grupos focales se evidenció que los niños y jóvenes del Centro Afro sienten ese miedo día a día en su barrio y en su ciudad por la constante violencia, ese miedo a no regresar a casa, un espacio como el Centro Afro es propicio para descansar de esa realidad y para encontrar otras alternativas de vida por medio de la apropiación cultural.

Este lugar se ha convertido en la segunda casa de los jóvenes y es un espacio seguro para ellos, en donde pueden jugar, cantar o bailar sin que nadie los detenga. Los niños que hacen parte de este centro son felices, y siempre están dispuestos a participar de manera alegre en las actividades, además, disfrutan pasar tiempo en su barrio y en sus casas con su familia, a pesar de la paradójica realidad que posee el Nuevo Milenio.

Muchos jóvenes que hacen parte del Centro Afro y que iniciaron desde muy pequeños el proceso, han sacado adelante una carrera y están ayudando a su comunidad. Son esos valores que se les inculcan a los nińos y jóvenes que permiten que ellos crezcan como personas, y que sus proyectos de vida cambien a algo que aporte a la comunidad.

Muestra de ello es que el Centro Afro ha logrado adaptarse a los distintos requerimientos que necesitan los chicos para crear un proyecto de vida. En ese 
sentido, es a través del arte popular que los más jóvenes del barrio Nuevo Milenio han logrado empoderarse con elementos locales y con lo propio: la memoria colectiva y la identidad afrodescendiente. El gancho es la danza, la música y los zancos. Son estas actividades la columna vertebral para que el niño o joven no caiga en actividades ilegales. La danza y la música que promueve el Centro Afro forma proyectos de vida, y con los zancos quieren divertir a los jóvenes con malabares para tenerlos distraídos.

La danza logra dirigir dos ramas que son la identidad y la memoria colectiva, ya que estas son danzas típicas de la etnia afrodescendiente, como el currulao, el patacoré, la caderona y el negrito, y que cuentan historias de esta población. Además de eso, en el Centro Afro lo muestran como un camino de vida.

Por otro lado, la música, que se expresa por medio del rap-consciencia, aporta en la memoria ya que a pesar de ser un tipo de música que no hace parte de la historia del municipio, sí ha dado a conocer por todo el mundo movimientos de negritudes para reclamar sus derechos, y esto es lo que hace Afromitu desde la cosmovisión afro y el contexto que se vive en el municipio, rescatando la riqueza cultural, los personajes más representativos y las expresiones que los hacen ser de su comunidad. Los zancos, que si bien no son actividades netamente afros, se han implementado con una forma de arte para que los jóvenes se distraigan y se afine su motricidad.

Esta adición de actividades también hace parte del contexto que se vive en la región y de la integración de nuevas culturas o actividades que no son propias del municipio. Esto tiene su lado negativo y su lado positivo. Por un lado, los medios de comunicación, Internet, el desarrollo del comercio y la globalización han logrado que nuevas imágenes de diferentes culturas modifiquen los significados y muchas veces predominen ideas que no se ajustan a la realidad de algunos contextos como la belleza occidental, que no aplica para razas como la afro y que por esta dominación, se ven relegadas o dejadas de lado.

Por otro lado, mucha información traída de otros contextos ha aportado para enviar mensajes contundentes como bien lo hace el rap, que como se mencionó, tiene unos orígenes distintos, es una forma musical y juvenil para llegar a la comunidad. Por otro 
lado, utilizar como herramientas actividades como los zancos, o tener mecanismos como Internet y los libros, permiten que los jóvenes tengan una visión más amplia de lo que hay en el mundo y esto es positivo para ellos.

Desafortunadamente, este trabajo con los jóvenes se desarrolla a largo plazo ya que, en muchos casos, no es suficiente proponer un proyecto de vida en tanto la ilegalidad atrae a los jóvenes, quienes ven este camino como una oportunidad para mejorar su calidad de vida o ayudar a su familia.

A pesar de esta realidad, los jóvenes que hacen parte del Centro Afro y que iniciaron desde muy pequeños el proceso, han sacado adelante una carrera y están ayudando a su comunidad. Son esos valores que les inculcan a los niños y jóvenes que permiten que ellos crezcan como personas y que sus proyectos de vida cambien a algo que aporte a la comunidad.

El trabajo que se realiza en el Centro Afro con los jóvenes y niños logra cambiar la perspectiva de sus vidas, ya que antes de entrar a ese lugar no piensan en su futuro, pero cuando están allí, desde la docencia y la coordinación, se logra que se cambien los proyectos de vida.

Esta investigación se alcanzó gracias a que hubo un proceso de inmersión en la comunidad y una constante conversación con cada una de las personas que colaboraron en este proyecto, tanto personalmente como ante cámara.

\section{REFERENCIAS}

Agier, M., Álvarez, M., Hoffman, O., y Restrepo, E. (1999). Tumaco: haciendo ciudad. Historia, identidad y cultura. Bogotá D. C., Colombia: Universidad del Valle.

Angulo, S. (2014). La música y la danza como factor de protección de la identidad en la población afrodescendiente desplazada: estudio de caso del grupo de danzas Palenkito del barrio 
Kennedy en Bogotá (tesis de grado, Maestría en Ciencia Política y Liderazgo Democrático), Instituto de Altos Estudios Europeos, Bogotá D. C., Colombia.

Aristizábal, M. (2005). El festival del currulao en Tumaco: dinámicas culturales y construcción de identidad étnica en el litoral pacifico colombiano. Recuperado de http://www.humanas. unal.edu.co/colantropos/files/2914/5615/3098/aristizabal_currulao.pdf

Arocha, J. (2004). Ley 70 de 1993: utopía para afrodescendientes excluidos. En J. Arocha (comp.), Utopia para los excluidos. El multiculturalismo en África y América Latina (pp. 159-178). Bogotá D. C., Colombia: Centro de Estudios Sociales, Universidad Nacional de Colombia.

Ávila, A. (2014). Red Nacional de Programas regionales de Desarrollo y Paz: Departamento de Nariño. Tercera monografía. Bogotá D. C., Colombia: Fundación paz y reconciliación.

Barrera Ramírez, V., García, M. C., Coronado Delgado, S., y Guzmán, T. (2016). Tendencias de la movilización social en municipios críticos para el posconflicto: principales hallazgos. Colección Documentos Ocasionales (80). Recuperado de http://biblioteca.clacso. edu.ar/Colombia/cinep/20160930043501/Doc.Ocasional80.MovilizacionPosconflicto. pdf

Cámara de Comercio de Tumaco. (2015). Estudios económicos. Recuperado de http://www.cctumaco.org/descargas/category/42-boletines- anuales. html?download=1428:estudios-economicos-2015-sic

Corbetta, P. (2007). Metodologías y técnicas de investigación social. Madrid, España: Editorial Interamericana de Espańa.

Corporación Autónoma Regional del Cauca. (1983). Consideraciones generales para un plan de desarrollo urbano de Tumaco. Cali, Colombia: Corporación Autónoma Regional del Cauca.

Dane. (2010). Censos y demografía. Recuperado de http://www.dane.gov.co/files/censo2005/ 
Dane. (2011). Proyecciones de población por departamento. Recuperado de https://www. dane.gov.co/files/investigaciones/poblacion/proyepobla06_20/ProyeccionMunicipios2005_2020.xls

Dane. (2015). Pirámide de población total según sexo y grupos quinquenales de edad. Recuperado de https://geoportal.dane.gov.co/midaneapp/pob.html

Echeverría, L. (2012). Prácticas de resistencia y construcción de ciudadanía en Tumaco: estudio de caso del proyecto educativo teatro por la paz desde los marcos de acción colectiva (tesis de grado. Maestría en Política Social). Pontificia Universidad Javeriana, Bogotá D. C., Colombia.

EFE. (2013). Victimas de conflicto colombiano cuentan su drama en espectáculo de danza. Recuperado de https://www.elespectador.com/noticias/cultura/ victimas-de- conflicto-colombiano-cuentan-su-drama-espec-articulo-464606

El Espectador. (2018a). Secuestro y asesinato de periodistas, una tragedia que Ecuador no conocía. Recuperado de https://colombia2020.elespectador.com/pais/ secuestro-y-asesinato-de- periodistas-una-tragedia-que-ecuador-no-conocia

El Espectador. (2018b). Nariño, sitiado por las disidencias de 'David' y 'Guacho'. Recuperado de https://colombia2020.elespectador.com/territorio/ narino- sitiado-por-las-disidencias-de-david-y-guacho

El Tiempo. (2017a). El $63 \%$ de la coca está solo en tres departamentos del país. Recuperado de www.eltiempo.com/justicia/conflicto-y- narcotrafico/ produccion-y-cultivo-de-coca-en-los-departamentos-de- colombia-2017-109304

El Tiempo. (2017b). 'Disidencias de las Farc están en proceso de expansión': Cerac. Recuperado de http://www.eltiempo.com/justicia/conflicto-y- narcotrafico/ en-tumaco-disidencias-de-las-farc-amenazan-la-convivencia- 139108 
Ensermua, F. (2018). Oasis donde brota la vida: sistematización de procesos educativos en el Centro Afro juvenil, barrio Nuevo Milenio, municipio de Tumaco (Tesis de maestría). Pontificia Universidad Javeriana, Cali, Colombia.

Escobar, C. (2014). Danzas folclóricas de Colombia, guía práctica para la enseñanza y el aprendizaje. Recuperada de www.banrepcultural.org/sites/default/files/lablaa/modosycostumbres/dancol/dancol.pdf

Figueroa, H., y Silva, L. (2014). Tradiciones y saberes populares de las comunidades negras del Pacífico sur (Colombia). Perspectivas: antes y después del desplazamiento. Recuperado de https://www.academia.edu/26955381/Tradiciones_y_saberes_populares_de_las_ comunidades_negras_del_Pac\%C3\%ADfico_Sur_Colombia_._Perspectivas_antes_y_ despu\%C3\%A9s_del_desplazamiento

Francia, M. (2012). Trabajo de memoria y arte popular. Recuperado de https://revistas.unlp. edu.ar/PLR/article/view/405

Frith, S. (2003). Música e identidad. Buenos Aires, Argentina: Amorrortu Editores.

García Canclini, N. (1977). Arte popular y sociedad en América Latina. México, D. F., México: Editorial Grijalbo.

García Canclini, N. (1994). Identidad cultural frente a los procesos de globalización y regionalización: México y el TLC de América del Norte. En M. Aglietta, C. Moneta y C. Quenan (comps.), Las reglas del juego. América Latina. Globalización y regionalismo (p. 274). Buenos Aires, Argentina.

García Canclini, N. (1995). Consumidores y ciudadanos: conflictos multiculturales de la globalización. México, D. F., México: Editorial Grijalbo.

García, A. (2003). La etnogénesis de los grupos negros e indígenas del Pacífico sur colombiano y la formación del Estado nacional. En Banco de la República (comps.), Informe de investigación presentado a la Fundación para la Promoción de la Investigación y la Tecnología (p. 141), Medellín, Colombia. 
García, J. (2015). Posconflicto y la revolución del arte en la sociedad colombiana. Lúdica Pedagógica, 2(22). DOI: https://doi.org/10.17227/01214128.3801. Recuperado de http:// revistas.pedagogica.edu.co/index.php/LP/article/view/3801

García, O., y Castillo, R. (1996). Territorio, poblamiento y sociedades negras en el Pacífico sur colombiano. En J. Del Valle y E. Restrepo (eds.), Renacientes del Guandal: "grupos negros" de los ríos Satinga y Sanquianga (p. 57). Bogotá D. C., Colombia: Universidad Nacional de Colombia.

Garner, H. (2001). Estructuras de la mente. La teoría de las inteligencias múltiples. México, D. F., México: Fondo de Cultura Económica.

Hall, S. (1992). New ethnicities. En J. Donald y A. Rattansi (eds.), 'Race', Culture and Difference (p. 252) London, UK: Sage Publications.

Hall, S. (1996). Introducción: ¿quién necesita identidad? En S. Hall y P. Du Gay (comps.). Cuestiones de identidad cultural (p. 15). Buenos Aires, Argentina: Amorrortu Editores

Halbwachs, M. (1992). On collective memory. Chicago: The University of Chicago Press, The Heritage of Sociology.

Hoffmann, O. (1999). ¿La "política” vs. "lo político”?: la estructuración del campo político contemporáneo en el Pacífico sur colombiano. En C. Agudelo, O. Hoffmann y N. Rivas, Hacer politica en el Pacifico sur: algunas aproximaciones, (pp. 39-71). Cali, Colombia: Universidad del Valle.

Jackson, P., y Penrose, J. (1993). Constructions of race, place, and nation. London, UK: University College London Press.

Jiménez, O, Hernández, D., y Pérez, E. (2005). Tumaco: historia, memoria e imagen. Tumaco, Colombia: Universidad de Antioquia.

Larios, L. (2018). Figura 1, resultado de taller realizado con los niños del Centro. 
Larios, L. (2018a). Figura 2, resultado de taller realizado con los niños del Centro.

Larios, L. (2018b). Figura 3, resultado de taller realizado con los niños del Centro.

Losonczy, A. (1999). Memorias e identidad: los negro-colombianos del Chocó. En J. Camacho y E. Restrepo (comps.), De montes, ríos y ciudades: territorios e identidades de la gente negra en Colombia (pp. 13-24). Bogotá D. C., Colombia: Juana Camacho y Eduardo Restrepo Editores.

Malo, C. (1996). Arte y cultura popular. Biblioteca Digital Andina. Universidad del Azuay. Recuperado de http://documentacion.cidap.gob.ec:8080/bitstream/cidap/299/1/ ARTE\%20Y\%20CULTURA\%20POPULAR\%20Segunda\%20edicion.pdf

Middleton, D. y Edwards, D. (1992). Memoria compartida. La naturaleza social del recuerdo y el olvido. Buenos Aires, Argentina: Paidós.

Ministerio de Cultura. (2014). Casas que cuentan: libro sonoro de las casas de cultura de Colombia. Recuperado de http://www.mincultura.gov.co/areas/fomento- regional/Documents/Libro_CASAS_Cultura_web.pdf

Mosquera, J. (2005). Estudios afrocolombianos. Recuperado de http://www.lablaa.org/blaavirtual/sociologia/cimarron/cimarron3.htm

Noticias Caracol. (12 de febrero de 2018). "No hay oportunidades y eso nos hace vulnerables": tumaqueños piden al Estado que no los olvide. [Archivo de video] Recuperado de https:// noticias.caracoltv.com/colombia/no-hay-oportunidades-y-eso-nos-hace-vulnerables-tumaquenos-piden-al-estado-que-no-los-olvide

Olaya, P., y Figueroa, C. (2015). El currulao: identidad cultural de Tumaco (tesis de grado, Maestría en Etnoliteratura). Universidad de Nariño, Pasto, Colombia.

Oslender, U. (1999). Espacio e identidad en el Pacífico colombiano. En J. Camacho y E. Restrepo (comps.), De montes, ríos y ciudades: territorios e identidades de la gente negra en 
Colombia (pp. 25-48). Bogotá D. C., Colombia: Juana Camacho y Eduardo Restrepo Editores.

Oviedo, R. (2009). Relatos, revueltas y desventuras de la gente entintada del Pacifico sur. Tumaco, Colombia: Departamento de Sociología Observatorio Social.

Payán, L. (2014). Saberes derivados de la práctica en la organización comunitaria "Sé quién soy" (tesis de pregrado). Pontificia Universidad Javeriana, Cali, Colombia.

Ramírez, S. (2011). Fortalecimiento de la identidad cultural y los valores sociales por medio de la tradición oral del Pacifico nariñense en la institución educativa Nuestra Señora de Fátima de Tumaco (tesis de grado de maestría). Universidad de Nariño, Pasto, Colombia.

Restrepo, E. (1999). Aletosos: dinámicas culturales en Tumaco. Recuperado de http://www. ram-wan.net/restrepo/documentos/aletosos.pdf

Restrepo, E. (2010). Respuestas a un cuestionario: posiciones y situaciones. En N. Richard (ed.), En torno a los estudios culturales: localidades, trayectorias y disputas. Santiago de Chile, Chile: Editorial ARCIS-Clacso.

Restrepo, J. (2016). El des-escalamiento del conflicto y el aumento de los cultivos de coca. Bogotá D. C., Colombia: Razón Pública. Recuperado de https://www.razonpublica.com/index. php/conflicto-drogas-y-paz-temas-\%2030/9621-el-des-escalamiento-del-conflicto-y-elaumento-de-los-cultivos-de-\%20coca.html

Sautu, R. (2004). El método biográfico: la reconstrucción de la sociedad a partir del testimonio de los actores. Buenos Aires, Argentina: Editorial Lumiere.

Spivak, G. (1996). The Spivak Reader. London, UK: Routledge.

Szurmuk, M. e Irwin, R. (2009). Diccionario de estudios culturales latinoamericanos. México. D. F., México: Siglo Veintiuno Editores. 